Journal Plus Education, ISSN: 1842-077X, E-ISSN (online) 2068-1151 Vol XIX (2018), No. 1. pp. 77-91

\title{
THE ROLE OF PUNISHMENT IN THE EDUCATIONAL SYSTEM \\ AND ITS EFFECTS ON THE DEVELOPMENT OF PERSONALITY
}

\author{
Maria LUNGU, Ph.D., \\ West University of Timişora \\ maria.lungu@yahoo.com
}

\begin{abstract}
Punishment is used in the educational system as a strategy to amend undesirable behaviour. The purpose is to determine the child to make a distinction between what is good and what is bad, between what is permitted and what is forbidden. By being punished the child is encouraged to amend his behaviour and find other ways in which to act, so that they will be accepted from a social and cultural point of view. By being punished, the child is forced to realize the connection between his behaviour and the consequences of his behaviour. The research done with the help of students from West University of Timisoara is trying to emphasize the positive or negative impact of punishment on the development of personality.
\end{abstract}

Key words: punishment; discipline; pupils / children; school; family;

\section{Introduction}

What does the punishment represent in the educational system? It is an instrument of action through which the child / pupil is forced / determined to modify his behaviour in a desired / accepted way by the parents or teachers.

The legitimacy of punishment in the educational system is attributed to the pedagogical thinking from the past. According to the "theory of mental discipline faculty", "man is naturally evil and forced labour for accomplishing difficult intellectual tasks is a useful exercise for strengthening will. (...) Children's failure in learning is considered to spring from stubbornness or laziness and so, being an immoral act, it imposed a harsh punishment." (Ausubel, Robinson 1981: 438).

Physical punishment played an important role in education. Marrou quoted by Skinner: "Education and corporal punishment seemed inseparable to a Greek, to a Jew or an Egyptian scribe from the time of the pharaohs." (Skinner 1971:89). 
Ross Campbell (2007:11) makes a distinction between education by reaction, which focuses on behaviour and proactive education, which takes care of children's needs. Education by reaction springs from the thinking system called behaviourism. The most important representatives of this current were: I. P. Pavlov (classical conditioning), E. L. Thorndike (learning by trial and error / trial and success, reward / punishment, the law of result), J. B. Watson and B. F. Skinner (operant conditioning). They have experimented with animal behaviour: dogs, cats, rats, pigeons etc. and have extended the results of their research to human behaviour as well.

What is specific to behaviourism is the fact that it deals only with measurable, observable behaviours. The causes of certain behaviours are to be found in the external environment, without taking into consideration the internal richness of the person. Behaviour is a response reaction to a stimulus from the environment.

Skinner sees behaviour as "operant" because it acts upon the environment in order to get the desired effect, as opposed to classical conditioning in which it reflexively responds to stimuli. Behaviour can be modified through its consequences. These can be positive reinforcement, negative reinforcement, which deals with avoidance of something unpleasant and punishment. Punishment refers to the application of an unpleasant stimulus after a response. Skinner considered that punishment weakens the response and decreases the possibility that it appears again. He says that resorting to punishment "must be done with the purpose to raise the moral level, to suppress mean actions and to beat down cravings" (1971:161). However, he thinks that punishment is not an effective mean of controlling behaviour because "where positive reinforcement builds behaviour, reinforcement as punishment seems to destroy it" (1971:160) - the explanation is that unwanted behaviour is suppressed without strengthening the desirable behaviour.

In our time behaviourist thinking is considered obsolete. Studies have proved that over short periods punishment seems to suppress undesirable behaviour, but even so, punishment would rather strengthen than reduce unwanted behaviour.

\section{Methodology}

The research was done during January-June 2017 period. The test sample was made up of 50 students from almost all faculties and from years I, II, III and Master's degree from West University of Timisoara. The research method was of qualitative nature - the partly structured interview, with the following key questions: if they have been punished, what sort of method was used; what did it mean for them; who punished them (the family, school); in what situation was the punishment used; how often have 
they been punished; how did they feel, what have they thought when they were punished; did they recognize their punishment; was their personality influenced by the punishment or not, etc.

\section{Research objectives:}

1. Defining the concept of punishment;

2. Identifying the causes that generate the use of punishment in the education of the child / pupil;

3. Identifying the punishment methods used in the educational system;

4. Analysing the ways in which the punishments influence personality development;

5. Alternate methods to punish.

\section{Research hypothesis}

The more often children are punished the more conformist they become and they develop various anxieties that affect their personality.

\section{Results}

1. S.F.

"The black dot. During the last but one kindergarten year I got a black dot because I did not want to sleep at noon. I clearly remember the effect of the two hours I spent in front of my colleagues with the black dot on my lapel. I spent two hours crying in my mother's arms once I got home and I decided I will never be put in that situation again and feel so bad in front of my colleagues. "You are allowed to read after you have finished studying for your instrument" - my mother would say during primary school. I usually preferred reading also because studying for my instrument was not an activity I came to enjoy yet. I felt a little compelled and many times I searched for a way to "dodge" studying and to read instead."

\section{L.M.}

Punishment: "the reading of extra books - my father would force me to read, to learn a poem by heart every day and this is why I started to hate reading; extra time for studying; extra days spent on duty (for example as a pupil on school duty); time spent isolated from friends. All these punishments made me accumulate lot of frustration and anger. I felt compelled and controlled."

\section{H.J.}

"If I was not doing well in school I would not receive my allowance or I was not allowed to go out with friends. I think I was most afraid of the lecture I would receive at home."

\section{D.B.}

"I was always scolded, but I was rarely beaten. My parents always preferred to "torture" me with a never-ending lecturing, mostly about homework. 
Now, thinking about it I realise it was not really a bad thing, but back then ... it seemed never-ending."

\section{R.N.}

"Because I could not read very well at the beginning of primary school my mother kicked me out on the staircase and threatened me she will send me to the orphanage. I really believed her and I was afraid it will happen. In school, the Maths teacher would insult me and all my colleagues."

\section{S.B.}

"If I would happen to get a bad mark in school my parents scolded me. For me this was an important punishment because I felt very guilty."

\section{F.B.}

"Unannounced test papers. When a colleague did not study or behaved badly we would get a test paper and usually we were not prepared for it. I felt this was not fair, but it would make me study harder in order to avoid such unpleasantness."

\section{T.C.}

"The humiliation from the part of some teachers. For example if I did not know how to solve a Maths exercise the teacher would force me to write in my notebook while standing in front of the class. That teacher made me hate Maths."

\section{C.A.}

Punishments: "scolding, dissatisfaction on the part of the parents, hating to read what was imposed."

\section{F.S.}

"The punishment I received especially from my mother was not physical. She preferred not to talk to me, and this thing hurt the most. Because we were both stubborn and vain, we would make up only after a day of not talking to each other. This made me ask for a lot of explanations when I argue with somebody. Only after the explanations would I calm down. In school the teachers punished me by forcing me to re-do my homework correctly. Thus I have discovered that a mistake can be amended."

\section{E.R.}

"When I was young and I would just be learning to write my father was the one who checked my homework. If I made any mistakes and "ate" any letters he would beat me. At present I think it had a good outcome because it taught me to be very neat in writing and in everything I do, but back then I felt frightened every time he would ask to check my homework."

\section{O.P.}

"When I was doing something wrong as a child the biggest punishment for me was to see my mum upset or for her not to talk to me anymore (for a while). In my $4^{\text {th }}$ grade I forgot my notebook at home with my civic education homework and the teacher thought I was lying because I did not do my 
homework. For this the teacher beat my palm with the ruler. I felt very humiliated and misunderstood. In another class I did not know a definition and I was punished to write it down 50 times. I found this really boring and inefficient."

\section{O.D.}

" $T V$ restrictions when I did not want to do my homework; threat with a belt beating - this happened only when I was little and my father would beat me when I was naughty. I was afraid, but I would do it again; laptop and phone restrictions when I was in high-school, after ten o'clock at night, because my parents thought I should be rested for school. This punishment made me feel that I was not allowed to manage my own time. In school: Cards - this system was applied in my school in order to sanction certain irregularities. They made me afraid all the time of what would happen if I do the wrong thing (for example, if you would not wear your uniform, if you were naughty or made noise) - the reason for this system was that they were not able to control the class otherwise. Applying the same treatment - the teacher would do to us the same thing we did to another pupil and ask us whether we liked it. This punishment made me understand that what I was doing was wrong and that I should consider the feelings of other pupils before hurting them. Bad marks: if I was being naughty, the teacher would quiz me and as a punishment he would give me a bad mark. I found this punishment was really unfair and Ifelt aggrieved."

\section{V.B.}

"The most used punishment in my family was the lack of pocket money for a week. My mother was the one who enforced this punishment but many times she forgot to inform our father that we were punished. So me and my brother would go and ask him for money and this is how we would cope. Another punishment my mother had for us was to not let us go out with friends; this is the one I hated the most."

\section{U.Y.}

"In our family most of the punishments were for moral things. For example, I was beaten because I stole some money when I was 9-10 years old. During primary school the biggest punishment for me were bad marks, followed closely by public scolding. I felt really ashamed, humiliated and misunderstood."

\section{T.G.}

"One of the most memorable punishments I received was when my father forced me to stand on my knees on corn kernels, in the corner. I don't remember why, but in primary school I pushed a girl off a rail. When I think about it, I am amused by the absurd punishment and I'm sure I could never do that to my child!" 
Journal Plus Education, ISSN: 1842-077X, E-ISSN (online) 2068-1151 Vol XIX (2018), No. 1. pp. 77-91

\section{J.S.}

"It was very important for me the way in which my parents received the information about my school situation. I was suffering very much when I got a bad mark because I knew my mother would be disappointed. My mother would always go to parents' meetings in school and I was always afraid of her reaction to finding out about my bad marks or an absence. If I knew she was upset about it, this was punishment enough for me."

\section{B.O.}

"I think the first punishment I remember was around the age of 4. I was visiting a friend and he had two identical toys, like those from Kinder eggs. I liked it so much, that I took one home with me. My mother saw it one night and told me: "I do not raise thieves I this house". Her words made me realize I did a very bad thing. The next day I apologised to the grandmother of my friend. I felt really bad. I never took anything without permission since then. The second punishment I remember has to do with the Maths class in my $4^{\text {th }}$ grade. Our teacher would give us maths problems to solve in class and I was not very good at it. Even now, I would rather do exercises alone at home than in class, where there is a certain pressure and I have to prove what I know. Back then I knew that the teacher was not in a good mood and that made it even harder for me to concentrate. She walked around the class and when she stopped behind me she had a look at my notebook and suddenly I felt her palm strike me on the back of my head. At that moment I felt like the stupidest girl in class and since then I have always hated teachers spying on my notes. This happened to me again during the Maths tests in my $8^{\text {th }}$ grade. The supervising teacher stopped and started reading my notes. At that moment I lost my train of thought and I was convinced that everything I wrote was wrong."

\section{E.S.}

Punishments: "my mother would always beat me when I got bad marks, but this influenced me in a bad way because after a while I would hide my bad marks from her. During one of the language classes I kept talking and the teacher moved me in one of the desks up front, alone. I felt a sort of hatred for the teacher, but in the end this was a good thing because I had no one to talk to and I stopped interrupting the class. I got a bad mark (3) in Romanian language class because I did not write an essay. Since then I always did my homework, whether it was correct or not."

\section{I.K.}

"When I was a child, until the end of the $8^{\text {th }}$ grade I was punished at home by my mother when my marks were bad. I was not allowed to watch TV and I was scolded for the bad results in school. I was learning as well as I could and I did all my homework because I did not want to disappoint my mother and be punished. In school I do not remember ever being punished by 
teachers because I was a good pupil and I was studying well. There were situations when I got a bad mark, but I did not interpret it as a punishment, because it was actually a correct consequence of my not being well prepared. As a result, the next time I would learn better and correct my mark. I was very ashamed if I got a bad marks and I wanted to hide this thing from my parents in order not to be punished. During high-school I was not punished for my marks, but even so, I was still afraid to get a bad mark and I was ashamed when it really happened. I think that fear of punishment frequently shaped my behaviour, especially as a child. At that age the punishment of not being allowed outside to play was very hard to accept."

21. F.A.

"In my family my mother was the one who punished me. She was of the opinion and still is, that in school you have to learn because this is its purpose. I did not agree with her then, but now I do. Usually I was punished for bad results in school. Otherwise I was a very good child, I did not make problems for my family. As a punishment I was not allowed to go outside and play, I was not allowed on the computer and to watch TV, and in the $6^{\text {th }}$ and $7^{\text {th }}$ grade they would take away my mobile phone. As far as the school punishment is concerned, the mark was very important. We could get a bad mark for general behaviour - this never happened to me, but I was "fined" in the $5^{\text {th }}$ grade with a very bad mark (1) because I whispered to a colleague the result to a maths problem. I was very upset that day, I cried a lot, but I understood that I was wrong and I did not do that again."

\section{T.X.}

"During my primary school I could not accept the idea of failure and I tried to hide it from my parents. I was in one of the first classes when I got a bad mark in maths. Because of my disappointment, I tried to avoid any other form of critic or punishment and I hid the fact from my parents. I managed to hide everything until my mother asked me directly about it. At that moment I had to come clean. When she found out about my lie, my mother was furious and she lectured me about the consequences of lying. She also forbids me to leave the house for a while. I was really amazed that she was more upset about the lying than about the bad mark I got. Even if at that moment my feelings went from fury to sadness and from pride to humiliation, I'm still feeling the effects of this punishment today. I learned that regardless of the nature of the problem, nothing justifies lying, and that the effects of this lack of trust can be forever."

\section{J.N.}

"My first punishment was during my $1^{\text {st }}$ grade when I had to finish for my homework the work we were doing in class - vertical bars. I wanted to do my homework alone, without my mother's help, I wrote in ink directly, I 
made a mistake and I tried to erase it, but I tore the page in that place, even if not too bad. For this I was punished by my mother with several hits on the bottom. It all seemed to me to be more important than it actually was. Besides, she also made me apologise to her for tearing a page in a notebook that was mine. After all this time I still blame her because I realised how deeply this situation affected me. I suffer from anxiety, I am always afraid not to make mistakes, I blame myself for things that are out of my control. I am still afraid to take initiative and I always try to consult with her when taking decisions. The second punishment I received was also during my primary school. I was punished for a mean note written by a colleague of mine to another colleague and then thrown in the bin. This note was then retrieved from the bin by a "charitable" colleague and then I was accused of writing and throwing it away. As a result, I was punished to stay in class and discredited in front of the class. I was shocked by this punishment; I did not know what was going on. I was being judgedwithout jury. Only the day after that did the teacher think to check the writing on the note. After they found out I was not guilty, it was very interesting to see that the colleague who really wrote the note was not even punished because her mother was a friend of the teacher. I felt stupid, insignificant and helpless. Now I am revolted and I have a bitter taste about school, equality, justice and respect for another person, even if it is not about a child. If you do not show respect, do not pretend to be respected."

\section{E.T.}

"The worst punishment I received was from my grandmother, who made me sit on the armchair in her room every time I had a fight with my brother or in another situation. I remember a time when I was in the same room with my brother and a friend of ours and we were bickering. My grandmother asked me to sit in that armchair even if I did nothing wrong. She always pretended she was "protecting" me when I was resentful. Every time she made me sit in that armchair I was feeling very frustrated and hateful towards my grandmother. This is proof of a punishment administered without analysing the situation, producing an unfounded injustice. Even at this age I still resent my grandmother. Another punishment used in the family and which was very painful for me was not being allowed to play on the computer for a certain time. I was very fond of the computer and not being allowed to use it was torture for me. I was punished in this way when I got bad marks in school. Also, the fact that my parents forced me to read was a punishment for me and I never liked it. This fact never encouraged me; to the contrary, it made me hate reading. Even now I read only what I am forced to read."

25. A.O.

"My father beat me for the first and last time when I was about 4 years old. I used to visit my older cousins and steal toys that I liked. I would take them 
home without saying a word. My aunt came to visit and saw all the toys from her boys and told my father. He cautioned me not to lie and steal ever again and then he beat me. Since then, I have never stolen anything else and when I am forced to lie, it is very hard for me to do it. That beating influenced me forever."

26. D.P.

"The worst marks I got during my first years of school. I think it was very difficult for me to study and I had real problems in Maths. What is even sadder is that my parents had very high expectations from my results. My father, especially, insisted to help me with my homework. I always thought of this as a true and harsh punishment. Besides the fact that I did not like maths and foreign languages, I was looking forward for the hours to pass and be able to go home. But at home the second round of torture would begin: homework. I was terrorised by homework and the subjects I found to be very hard. At that time, punishment meant the harsh words of my parents, colleagues and teachers. Those statements and replies were very painful and stressful!"

\section{U.F.}

"When I was 4 or 5 years old I said some very rude words to my grandmother and my mother heard me and she beat me for it. I felt really frustrated and mad at my mother for punishing me. But now I am grateful to my mother for that punishment, because even if it has already been 16 years since then, I have never again said anything rude to my grandmother. There was also another punishment I received around that period. I was together with my cousin and we were both looking after my little sister. We kept playing with the swing and at some point we dropped it out of our hands and it fell together with my sister. My mother was the one that punished me again and she broke a willow twig hitting me over my arms and legs. That was not a pleasant situation and I got marks all over my arms and legs, but later I understood that I was punished because I was not responsible. This punishment and others have helped me become a responsible person and be careful what I'm doing and saying."

\section{L.B.}

"I remember the time when my father punished me and my sister when he found us arguing. He made us stay in the corner for 10 minutes and think about what we did wrong and then apologise to one another. I know that at the time I hated my sister because I thought she was the only one to blame. I felt furious and hated that I had to stay in the corner. On the other hand, this experience has taught me that we must admit when we are wrong and always apologise."

29. M.M. 
"The person that punished me the most was my mother. When I got bad marks in school or when I was not obedient I was not allowed to go out on weekends. I was really upset with her at those times. All the children were allowed to go out but I had to stay indoors. I was also punished when I was fighting with my brother and my parents usually told me that I was the one to blame for what was going on. I always got the feeling that they loved him more than they loved me and I was jealous."

\section{I.U.}

"As far as I remember my mother punished me when I did not respect the play time and when I was not to be found where she knew I was supposed to be. I was almost 6 years old and my mother would let me play outside our block of flats with the other children. When my mother considered I had wondered around enough, she would come and get me and if she could not find me where I was supposed to be, then she would punish me. At first the punishments were not very harsh - I was not allowed to play outside for a while. But they seemed to be inefficient, because I kept disappearing from the playground and my mother started to punish me by making me sit in the corner on my knees and with my hands raised. She would keep guard so that I could not let my hands down. I did not feel good about being punished, but I knew the reason I was punished and that I deserved it for breaking the rules."

In above interviews we can see that punishments were applied at home and in school and that they came from parents and teachers alike. They have been physical or psychicviolence.

The following have been seen as punishment: beating, standing in the corner on one's knees on corn kernels, insults, humiliations, denigration in front of the classroom, unannounced tests in class just because somebody had inappropriate behaviour, sitting in the corner, writing a word / text a certain number of times, restricting access to TV, computer, mobile phone, forbidding to go out or play with friends.

The following have also been seen as punishments: imposed reading of certain books or doing certain intellectual activities, such as studying a certain instrument; low grades given in school, black dots, penalty cards, prolonged study time or school activities, moralising talk for inappropriate behaviour, critics, scolding etc. Silent treatment to a child, threat of abandonment, displeased parents about school results have produced a lot of sadness, pain and suffering. All these attitudes have been decoded by the child, treated as a worthless person, as being rejected or lacking affection from the parents.

What were the reasons for which they were punished? Punishments inflicted on children/ pupils have most of the time been connected to the lack 
of accomplishment in school activities, such as: not doing one's homework, low grades or the failure to attain the standards imposed by school or family. Other causes have been connected to discipline, behavioural problems or attitude.

Have the punishments been effective in administration? A small part of the interviewed persons has considered that yes, they have been effective in the sense that have become more responsible, neat, disciplined, had better results in school, so in other words they have managed to conform to the expectations of parents and teachers. When did they find this out? onlywhen the punishment was explained, when it came immediately after the inappropriate behaviour or when empathy was used.

On the other hand, most of the interviewed persons consider that the punishment was not effective, it produced anger, fear, humiliation, hate, jealousy, revolt, the feeling that they are misunderstood, sense of discomfort, guilt. The punishment made them feel coerced, controlled, helpless, and insignificant, aggrieved, discriminated against, worthless. Even those who considered punishments as effective in the end admit that they were scared when the punishments were applied.

\section{Conclusions}

Punishment is an educational method for children meant to discipline them. Allegations such as "Beating comes from heaven", "Beating made me a real man" or "When you mother / father beats you, you will be fine" are still frequently used today.

Punishment or sanction is used just as much at school as at home, as a method of exerting external control by imposition (you must!) or force over children / pupils in order to get the modifications desired by adults in behavioural and attitudinal level.

Do punishments accomplish their objectives? On short term they do, in the sense that the child "becomes good" or is silenced and the problem is solved on the spot. The adult justifies his gesture: "look, this is what he needed in order not to be impertinent any more". I. Kant thinks that punishment applied "while angry" misses the point and determines the child to buckle under as a reflex, making him "act subserviently". "When physical punishment is frequently repeated they produce some disobedient characters and when parents punish their children for their selfishness they become even more selfish. Rarely the worse people are those who do not comply, but most of the time these are the ones who comply with a well-made observation" (1992:57).

On the long term and especially when punishments are frequent they become habitual and lose their effectiveness and value. According to Andre Berge, as a result of frequent punishment children form "a crust of 
indifference" and become "insensitive to the most illuminating arguments". Also there are educators who, when faced with a small mistake made by a child, remind him of "all the past mistakes". This "contributes to the development of a guilty personality based on the model which we had the imprudence to build ourselves in order to lay it in front of him" (Berge 1972:215).

As we have seen from above interviews, punishment can have a detrimental effect on the personality of the child / pupil. Why is that? Because they will ignite fury, resentment, revolt etc. Punishment as an educational mean generates fear and not respect. Children will learn to fear the consequences! Also it is a known fact that children / pupils find all sorts of subterfuges or motivations in order not to respect the punishment. "If they are punished children become more cautious, not more obedient or responsible" (Ginott 2006:111). Ginott also states that physical violence "dissolves the guilt too easily: the child, having paid for the bad behaviour, feels entitled to repeat it. (...) Children develop a so-called "accounting" ability towards his bad behaviour. He can afford to be bad and so become indebted and then he pays by weekly or monthly "deposits" of beatings. Periodically they start a fight by inciting the parents. Sometimes they even ask for the punishment or punish themselves" (Ginott 2006:127).

Still, why do we apply punishment in the educational system? On the one hand because they are easy to apply and you get to see the result immediately - the child was silenced or he sits still! On the other hand because adults have seen this as well in their parents, which means that this is a learned behavioural pattern.

Punishment is used with the purpose to discipline the child / pupil. But in order to discipline the child I believe there are needed some clear and decisive limits and rules, applied with kindness.

It is very important in disciplining that the rules be flexible and be redefined according to the age of the child and the existing context. Rigid rules will build a personality which lacks adaptability. Also while establishing the rules and limits it is very important to involve and consult the child so that he can become responsible. He must also be offered alternatives and must be informed of the consequences of stepping over the limits.

Zig Ziglar (2000:69) quotes John Drescher who says that children go through three age phases. The first one is 1-7 years, in which the rules are extremely important. During this period child live in a world of feelings and explorations and not one of rationality. This is the period when they develop from a moral point of view and they need safety and predictability. They must know exactly what is expected of them. Even if they are discontent, constantly testing the limits of adults, they do this in order to "force" the 
adults to take over their actions and their deeds. It is very important for children to feel that the parent / the educator is in control.

At this age child do not know how to cope with freedom and control. They do not need them because they don't know how to use them! If the limits are not clear children can become unmanageable and thus they will suffer a lot when they will not understand why other children do not tolerate their attitude and behaviour. They will feel rejected, unloved and will not be able to understand why this is happening to them! This thing will have repercussions over their self-esteem and self-image. Zig Ziglar considers that parents who manage to impose clear limitations at this age will be able to "relax" during the adolescence of their children because these rules will already be interiorized and when the children will be faced with inappropriate challenges their inner voice will be able to say NO.

The second age phase, 8-12 years, is characterised by imitation. During this period, it is more important what the parent or teacher does than what he says.

During this period imitation has more consistency than rules. What can a child learn from the fact that adults, when faced with a problem, start applying punishments by force, intimidation, threat etc.? He will learn that the strong ones have the power and that they are the only ones that can decide. So children, in order to be alright, must conform to this. In turn, they will use force, intimidation, threat, rejection or raised voice in order to solve problems or find solutions because this is what they have seen and learned in school and at home. Punishments make children hostile and vengeful.

How should one act in the situation when punishment is necessary? It must be matched to the deed, it must be clear, decisive and applied on the spot otherwise the child will be confused and he will not understand why he is punished. The issue with punishment is that it teaches the child / pupil only what he is not supposed to do. For example: don't write on the table or you will be punished; don't push your colleague or you will be punished; don't curse or you will be punished etc. So how should one react, what sort of behaviour or attitude should a child / pupil have when his playmates, schoolmates, teachers and parents beat him and humiliate him? Punishment only underlines the mistake, the wrong thing, what should not be done - but children / pupils are in the process of exploration, of testing the limits and controls of adults, of searching for their identity during adolescence. That is why mistakes must be viewed as a source as learning.

If the child makes a mistake or has an undesirable behaviour the adult must talk to him and explain to him what was wrong, what was the reason for which he acted that way, how he sees what happened through the perspective of his age, what he thought, what he felt, what would be the solution, what are the alternatives and what is expected from him. In case the 
punishment must be applied then it must happen immediately after the wrong behaviour so that the child must make the connection. It must be a consequence of not respecting the rule - rule which was discussed with the child beforehand. For example, if he did not do his homework he is not allowed to watch TV or go out with friends and as a result he must use that time to do the homework that he did not do at the right time. The child must recognize the consequences of not respecting the rules.

It is also very important to help the child / pupil understand that the punishment is related to his deeds and not to what he is as a person. Otherwise the child / pupil will believe that he is "incapable", "bad", "stupid", that "he can't do any better, so why bother". In this way his selfimage ("I am worthless", "I can't think better", "I am incapable", "I can't do any better", "I don't deserve to be loved") and his self-esteem (lack of confidence in his own powers) will be seriously affected. They will also develop a series of negative behaviours such as skipping school, lying, stealing, alcohol and drugs consumption, etc.

As a result, the child will not be able to assume responsibilities or perform his tasks because he will be afraid - afraid to fail, to do something wrong and be judged again, sanctioned or punished. They can also develop a series of emotional disorders (various fears, terrors, shame, guilt etc.) Repeated punishment may induce in a child the sense that he cannot please and it can cause various blockages so that he will abandon any effort and will try to attract attention in a negative way with all sorts of undesirable behaviours or attitudes.

I think that the question that we as educators must ask ourselves is the following: what is it that our punishments solve? Do we solve the behavioural or attitude problem of the child / pupil or our own problem?

I think we start to dish out punishments when we reach our highest point of helplessness, when we feel we have been overwhelmed in our role as parent or teacher and we cannot manage our emotions, be they fear, guilt or shame and we manifest ourselves with anger, raised voice or hitting.

So on one hand it is about the inefficient management of emotions and on the other hand our own behavioural manifestation has to do with our needs. It is about our need as parents / teachers to feel competent and validated in our role as parent / teacher, to feel in control, to make ourselves heard, to feel respected, appreciated and important. It has to do with selfesteem and self-image.

In case these human needs are not fulfilled they will trigger all sorts of fears and terrors that manifest at behavioural level through anger, nerves, raised voice, hitting, humiliation, denigration, rejection ("leave me alone, can't you see how busy I am?"). 
As a conclusion, our unfulfilled needs as teachers / parents have a direct effect on the needs of our children / pupils (the need to be respected, appreciated, valued, encouraged supported, the need to be heard, seen, understood, the need to be unconditionally loved by our parents, the need for stability and predictability, the need for autonomy, of emotional safety, the need to be accepted etc.). The unfulfilled needs of adults reflect upon important needs of children, generating a lot of pain and suffering. When adults in the process of educating start to use labelling, humiliation, sarcasm, irony or shame motivationally and with good intention in the relation with the child / pupil the only result they get is emotional disconnection.

We can control the behaviour of the child / pupil but we cannot control his thinking and feelings. The need of the child for safety, acceptance and appreciation makes him disciplined, obedient, but at the same time resigned, oppressed and subordinated.

I believe that discipline is based on a strong connection between parent / teacher and child / pupil, which means getting on the same page with the needs of the child. This connection develops in children the ability to learn, understand, respect and accept the limits and rules that were mutually agreed. In order to do this, as an educator you need to be patient, empathic and kind during the educational process. It is very important that when we offer children alternatives they should feel that we are on their side and that we only want to meet their most important needs when we have expectations from them.

\section{References:}

Ausubel, D.P.,Robinson F.G (1981). Învăţarea în şcoală, Bucureşti: Editura Didactică şi Pedgogică.

Berge, A. (1972). Copilul dificil, Bucureşti, Editura Didactică şi Pedagogică. Campbell, R. (2007). Educaţia prin iubire, Bucureşti: Editura Curtea Veche. Ginott, G. H. (2006), Intre părinte şi copil, Editura Humanitas, Bucureşti

Kant, I. (1992). Tratat de pedagogie, Iaşi: Editura „Agora” S.R.L.

Skinner, B.F. (1971). Revoluţia ştiinţifică a învăţământului, Bucureşti: Editura Didactică şi Pedagogică.

Thornidike, E.L. (1983). Invăţarea umană, București: Editura Didactică şi Pedagogică.

Zglar, Z. (2000). Putem creşte copii buni într-o lume negativă, Bucureşti:

Editura Curtea Veche. 